\title{
Effect of pre-harvest spray of calcium nitrate, boric acid and zinc sulphate on storability of Nagpur mandarin (Citrus reticulata Blanco)
}

\author{
Manish Kumar Meena ${ }^{1 *}$, M. C. Jain ${ }^{1}$ and Pravin Singh ${ }^{2}$ \\ ${ }^{1}$ Department of Fruit Science, College of Horticulture \& Forestry, (Agriculture University, Kota) Jhalarapatan city, \\ Jhalawar-326023 (Rajasthan), INDIA \\ ${ }^{2}$ Department of Vegetable Science, College of Horticulture \& Forestry, (Agriculture University, Kota) Jhalarapatan \\ city, Jhalawar-326023 (Rajasthan), INDIA \\ *Corresponding author. E-mail: manishkhamrya@gmail.com
}

Received: May 31, 2016; Revised received: February 14, 2017; Accepted: June 25, 2017

Abstract: An investigation was carried out at Fruit Research Farm, Department of Fruit Science at College of Horticulture and Forestry, Jhalawar during 16 September, 2014 to 1 March, 2015 to study the individual effect of Pre -harvest spray of Calcium nitrate, Zinc sulphate and Boric acid as well as their interaction on Storability of Nagpur mandarin (Citrus reticulata Blanco) after fruit set stage. Among different pre-harvest treatments, $\mathrm{T}_{27}$ treatment (Ca $3.0 \%+\mathrm{B} 0.6 \%+\mathrm{Zn} 0.6 \%$ ) treated fruits had the longest shelf-life of 15 days at ambient conditions with lowest PLW $(9.27 \%)$, decay per cent $(15.23 \%)$ and better organoleptic ratting $(8.41 / 10)$ and higher retention of juice percent $(39.12 \%)$ till end of storage period.

Keywords: Boric acid, Calcium nitrate, Pre-harvest spray, Storability, Zinc sulphate

\section{INTRODUCTION}

Mandarin is considered to be one of the most important cultivated species among citrus groups. Among the various citrus species, mandarin, sweet orange and lime are the common citrus fruits having 50,21 and 15 per cent of total area under them, respectively. Nagpur mandarin is being commercially grown in specific region of the country like Nagpur mandarin in Central India, Khasi mandarin in North Eastern regions and Coorg mandarin in Southern regions. The total production of mandarin in India is 34.31 lakh tonnes from an area of 330.0 thousand hectares with the productivity of 10.4 MT/ha. In Rajasthan mandarin covers 11.20 thousand hectares area producing 229.90 thousand MT with the productivity of $20.5 \mathrm{MT} / \mathrm{ha}$. In the state, In Jhalawar district mandarin where it is grown over 37,251 ha area, 11,323 ha of which are in the fruit bearing stage and the production is 2.5 Lac tonnes (Anonymous, 2015).Post-harvest losses in fruits and vegetables range from $20 \%$ to $40 \%$ or even greater. The post-harvest losses in citrus fruits are estimated to about $9 \%-25 \%$ and could be as high as $35 \%$ (Sajidet al. (2012). Since the demand of fruit is increasing in the market, thereby to achieve higher yield of good quality fruit with longer storage life become the priority. Therefore, both pre- and post-harvest management technologies need to be optimized for quality fruit production and retention of quality during storage.The adoption of poor production practices such as low yielding genotypes, deficiency of nutrients specially the micronutrients and post-harvest problems such as poor sorting and grading, moisture condensation resulting in pathogen infestation, improper transportation and storage and distant and time consuming marketing are the major causes of losses in quality and quantity (Chaturvedi et al., 2007).A very few studies have investigated the influence of calcium, Boron and Zinc on the storability of Nagpur mandarin fruits and the results have been quite non-persistent. The present experiment was conducted to investigate the influence of calcium, boron and zinc on the storability of Nagpur mandarin fruits.

\section{MATERIALS AND METHODS}

The present investigation was carried out on eight years old Nagpur mandarin (C. reticulata Blanco.) of uniform size and growth at the Fruit research farm, Department of Fruit Science, College of Horticulture and Forestry, Jhalawar during the year 2014-15. The selected plants were sprayed with Calcium nitrate (1.0, 2.0 and 3.0 per cent), Boric acid (0.2, 0.4 and 0.6 per cent) and Zinc sulphate (0.2, 0.4 and 0.6 per cent). The treatments consisted of three different chemical namely calcium nitrate Boric acid and Zinc sulphate and with three concentrations of each. The plain distilled water was sprayed on the plants for control. In this way total 27 treatments were used in this experiment. This experiment was laid out in Factorial Randomized Block Design (RBD) with three replications. The fac- 
Table 1. Interaction effect of pre-harvest spray of calcium nitrate, boric acid and zinc sulphate on Physiological loss in weight at $5^{\text {th }}, 10^{\text {th }}$ and $15^{\text {th }}$ day of storage of Nagpur mandarin.

\begin{tabular}{|c|c|c|c|c|}
\hline & eatments & & gical Los & W \%) \\
\hline & & 5-days & 10-days & 15-days \\
\hline $\mathrm{T}_{0}$ & $\mathrm{Ca}_{0} \mathrm{~B}_{0} \mathrm{Zn}_{0}$ & 3.12 & 6.72 & 11.42 \\
\hline $\mathrm{T}_{1}$ & $\mathrm{Ca}_{1} \mathrm{~B}_{1} \mathrm{Zn}_{1}$ & 3.10 & 6.62 & 11.39 \\
\hline $\mathrm{T}_{2}$ & $\mathrm{Ca}_{1} \mathrm{~B}_{1} \mathrm{Zn}_{2}$ & 3.02 & 6.41 & 11.27 \\
\hline $\mathrm{T}_{3}$ & $\mathrm{Ca}_{1} \mathrm{~B}_{1} \mathrm{Zn}_{3}$ & 2.97 & 6.28 & 11.04 \\
\hline $\mathrm{T}_{4}$ & $\mathrm{Ca}_{1} \mathrm{~B}_{2} \mathrm{Zn}_{1}$ & 3.05 & 6.34 & 11.14 \\
\hline $\mathrm{T}_{5}$ & $\mathrm{Ca}_{1} \mathrm{~B}_{2} \mathrm{Zn}_{2}$ & 3.12 & 6.21 & 11.14 \\
\hline $\mathrm{T}_{6}$ & $\mathrm{Ca}_{1} \mathrm{~B}_{2} \mathrm{Zn}_{3}$ & 2.91 & 6.11 & 10.97 \\
\hline $\mathrm{T}_{7}$ & $\mathrm{Ca}_{1} \mathrm{~B}_{3} \mathrm{Zn}_{1}$ & 2.82 & 6.02 & 10.84 \\
\hline $\mathrm{T}_{8}$ & $\mathrm{Ca}_{1} \mathrm{~B}_{3} \mathrm{Zn}_{2}$ & 2.74 & 5.91 & 10.78 \\
\hline $\mathrm{T}_{9}$ & $\mathrm{Ca}_{1} \mathrm{~B}_{3} \mathrm{Zn}_{3}$ & 2.62 & 5.84 & 10.67 \\
\hline $\mathrm{T}_{10}$ & $\mathrm{Ca}_{2} \mathrm{~B}_{1} \mathrm{Zn}_{1}$ & 2.52 & 5.63 & 10.78 \\
\hline $\mathrm{T}_{11}$ & $\mathrm{Ca}_{2} \mathrm{~B}_{1} \mathrm{Zn}_{2}$ & 2.34 & 5.27 & 10.45 \\
\hline $\mathrm{T}_{12}$ & $\mathrm{Ca}_{2} \mathrm{~B}_{1} \mathrm{Zn}_{3}$ & 2.43 & 5.55 & 10.23 \\
\hline $\mathrm{T}_{13}$ & $\mathrm{Ca}_{2} \mathrm{~B}_{2} \mathrm{Zn}_{1}$ & 2.23 & 5.21 & 10.34 \\
\hline $\mathrm{T}_{14}$ & $\mathrm{Ca}_{2} \mathrm{~B}_{2} \mathrm{Zn}_{2}$ & 2.18 & 5.08 & 10.14 \\
\hline $\mathrm{T}_{15}$ & $\mathrm{Ca}_{2} \mathrm{~B}_{2} \mathrm{Zn}_{3}$ & 2.04 & 4.94 & 9.82 \\
\hline $\mathrm{T}_{16}$ & $\mathrm{Ca}_{2} \mathrm{~B}_{3} \mathrm{Zn}_{1}$ & 2.13 & 5.05 & 10.04 \\
\hline $\mathrm{T}_{17}$ & $\mathrm{Ca}_{2} \mathrm{~B}_{3} \mathrm{Zn}_{2}$ & 2.02 & 4.88 & 9.92 \\
\hline $\mathrm{T}_{18}$ & $\mathrm{Ca}_{2} \mathrm{~B}_{3} \mathrm{Zn}_{3}$ & 1.94 & 4.81 & 9.87 \\
\hline $\mathrm{T}_{19}$ & $\mathrm{Ca}_{3} \mathrm{~B}_{1} \mathrm{Zn}_{1}$ & 1.81 & 4.78 & 9.81 \\
\hline $\mathrm{T}_{20}$ & $\mathrm{Ca}_{3} \mathrm{~B}_{1} \mathrm{Zn}_{2}$ & 1.67 & 4.54 & 9.74 \\
\hline $\mathrm{T}_{21}$ & $\mathrm{Ca}_{3} \mathrm{~B}_{1} \mathrm{Zn}_{3}$ & 1.72 & 4.47 & 9.55 \\
\hline $\mathrm{T}_{22}$ & $\mathrm{Ca}_{3} \mathrm{~B}_{2} \mathrm{Zn}_{1}$ & 1.64 & 4.51 & 9.77 \\
\hline $\mathrm{T}_{23}$ & $\mathrm{Ca}_{3} \mathrm{~B}_{2} \mathrm{Zn}_{2}$ & 1.55 & 4.42 & 9.61 \\
\hline $\mathrm{T}_{24}$ & $\mathrm{Ca}_{3} \mathrm{~B}_{2} \mathrm{Zn}_{3}$ & 1.34 & 4.23 & 9.41 \\
\hline $\mathrm{T}_{25}$ & $\mathrm{Ca}_{3} \mathrm{~B}_{3} \mathrm{Zn}_{1}$ & 1.52 & 4.40 & 9.52 \\
\hline $\mathrm{T}_{26}$ & $\mathrm{Ca}_{3} \mathrm{~B}_{3} \mathrm{Zn}_{2}$ & 1.37 & 4.36 & 9.49 \\
\hline $\mathrm{T}_{27}$ & $\mathrm{Ca}_{3} \mathrm{~B}_{3} \mathrm{Zn}_{3}$ & 1.24 & 4.17 & 9.27 \\
\hline $\mathrm{SEm} \pm$ & & 0.05 & 0.06 & 0.08 \\
\hline C.D. at $5 \%$ & & 0.14 & 0.16 & 0.20 \\
\hline
\end{tabular}

Here- $\mathrm{Ca}_{1-}$ Calciun nitrate $1 \%, \mathrm{~B}_{1-}$ Boric acid $0.2 \% \mathrm{Zn}_{1-}$ Zinc sulphate $0.2 \%$; $\mathrm{Ca}_{2-}$ Calciun nitrate $2 \%, \mathrm{~B}_{2-}$ Boric acid $0.4 \%$,

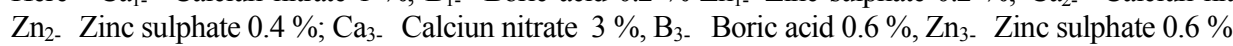

tors of experimentation comprising of 28 treatment combinations to study the effect of pre-harvest spray of Calcium nitrate, Zinc sulphate and Boric acid on storability of Nagpur mandarin (C.reticulata Blanco). The treatments were applied during second week of September, 2014 after selection of good uniform size and bearer plant. The observations were recorded on different aspects viz. storability of fruits (physiological loss in weight, decay per cent, juice per cent and sensory score to assess the impact of pre-harvest spray on above mentioned storability attributes of Nagpur mandarin. The data generated during the experimentation were subjected to statistical analysis of variance. The significance of the treatments was tested through ' $F$ ' test at 5 per cent level of significance. The critical difference was calculated to assess the significance of difference among the different treatments as described by Fisher (1950).

\section{RESULTS AND DISCUSSION}

From the investigation, it is evident that the physiological loss in weight increased continuously from incep- tion of study till the end of storage period irrespectively of different 27 treatments applied (Table-1). The PLW per cent of Nagpur mandarin fruits (1.24\%), $(4.17 \%)$ and $(9.27 \%)$ was recorded minimum with treatment $\mathrm{T}_{27}$ (calcium nitrate@3 per cent + boric acid@0.6 per cent+Zinc sulphate@0.6 per cent) at $5^{\text {th }}, 10^{\text {th }}$ and $15^{\text {th }}$ day of storage at ambient temperature respectively. However, the maximum PLW (3.12\%), $(6.72 \%)$ and $(11.42 \%)$ was recorded under control at $5^{\text {th }}, 10^{\text {th }}$ and $15^{\text {th }}$ day of storage, respectively. The losses during the study periods occurred as a result of moisture loss from fruit skin through respiration and transpiration. Similar results have also been reported by Dawood et al. (2002) and Yang and Lee (2003) who reported minimum PLW in mandarin over control at end of storage periods.

The data in (Table 2) further reveal that effect of calcium nitrate, boric acid and zinc sulphate was significant on decay per cent of Mandarin fruits. The decay per cent increased gradually with the increase in the storage period in all the treatments. The minimum decay per cent $(15.23 \%)$ was recorded with treatment $\mathrm{T}_{27}$ 
Table 2. Interaction effect of pre-harvest spray of calcium nitrate, boric acid and zinc sulphate on decay per cent at $5^{\text {th }}, 10^{\text {th }}$ and $15^{\text {th }}$ day of storage of Nagpur mandarin.

\begin{tabular}{|c|c|c|c|c|}
\hline & Treatments & & Decay & \\
\hline & & $5^{\text {th }}-$ day & $10^{\text {th }}-$ day & $15^{\text {th }}-$ day \\
\hline $\mathrm{T}_{0}$ & $\mathrm{Ca}_{0} \mathrm{~B}_{0} \mathrm{Zn}_{0}$ & 7.72 & 16.89 & 28.44 \\
\hline $\mathrm{T}_{1}$ & $\mathrm{Ca}_{1} \mathrm{~B}_{1} \mathrm{Zn}_{1}$ & 7.11 & 16.34 & 28.33 \\
\hline $\mathrm{T}_{2}$ & $\mathrm{Ca}_{1} \mathrm{~B}_{1} \mathrm{Zn}_{2}$ & 6.67 & 16.34 & 27.78 \\
\hline $\mathrm{T}_{3}$ & $\mathrm{Ca}_{1} \mathrm{~B}_{1} \mathrm{Zn}_{3}$ & 6.67 & 16.00 & 27.34 \\
\hline $\mathrm{T}_{4}$ & $\mathrm{Ca}_{1} \mathrm{~B}_{2} \mathrm{Zn}_{1}$ & 7.23 & 15.56 & 27.78 \\
\hline $\mathrm{T}_{5}$ & $\mathrm{Ca}_{1} \mathrm{~B}_{2} \mathrm{Zn}_{2}$ & 6.34 & 15.56 & 26.89 \\
\hline $\mathrm{T}_{6}$ & $\mathrm{Ca}_{1} \mathrm{~B}_{2} \mathrm{Zn}_{3}$ & 6.34 & 14.24 & 26.50 \\
\hline $\mathrm{T}_{7}$ & $\mathrm{Ca}_{1} \mathrm{~B}_{3} \mathrm{Zn}_{1}$ & 5.67 & 14.24 & 27.34 \\
\hline $\mathrm{T}_{8}$ & $\mathrm{Ca}_{1} \mathrm{~B}_{3} \mathrm{Zn}_{2}$ & 6.12 & 13.89 & 24.50 \\
\hline $\mathrm{T}_{9}$ & $\mathrm{Ca}_{1} \mathrm{~B}_{3} \mathrm{Zn}_{3}$ & 5.00 & 13.33 & 24.89 \\
\hline $\mathrm{T}_{10}$ & $\mathrm{Ca}_{2} \mathrm{~B}_{1} \mathrm{Zn}_{1}$ & 5.33 & 12.68 & 24.34 \\
\hline $\mathrm{T}_{11}$ & $\mathrm{Ca}_{2} \mathrm{~B}_{1} \mathrm{Zn}_{2}$ & 5.50 & 12.34 & 22.23 \\
\hline $\mathrm{T}_{12}$ & $\mathrm{Ca}_{2} \mathrm{~B}_{1} \mathrm{Zn}_{3}$ & 4.67 & 12.50 & 23.50 \\
\hline $\mathrm{T}_{13}$ & $\mathrm{Ca}_{2} \mathrm{~B}_{2} \mathrm{Zn}_{1}$ & 4.44 & 13.23 & 22.23 \\
\hline $\mathrm{T}_{14}$ & $\mathrm{Ca}_{2} \mathrm{~B}_{2} \mathrm{Zn}_{2}$ & 4.11 & 11.11 & 20.77 \\
\hline $\mathrm{T}_{15}$ & $\mathrm{Ca}_{2} \mathrm{~B}_{2} \mathrm{Zn}_{3}$ & 3.89 & 10.34 & 20.34 \\
\hline $\mathrm{T}_{16}$ & $\mathrm{Ca}_{2} \mathrm{~B}_{3} \mathrm{Zn}_{1}$ & 3.33 & 11.44 & 20.77 \\
\hline $\mathrm{T}_{17}$ & $\mathrm{Ca}_{2} \mathrm{~B}_{3} \mathrm{Zn}_{2}$ & 2.23 & 10.34 & 18.44 \\
\hline $\mathrm{T}_{18}$ & $\mathrm{Ca}_{2} \mathrm{~B}_{3} \mathrm{Zn}_{3}$ & 3.33 & 10.27 & 20.11 \\
\hline $\mathrm{T}_{19}$ & $\mathrm{Ca}_{3} \mathrm{~B}_{1} \mathrm{Zn}_{1}$ & 2.23 & 10.11 & 18.23 \\
\hline $\mathrm{T}_{20}$ & $\mathrm{Ca}_{3} \mathrm{~B}_{1} \mathrm{Zn}_{2}$ & 1.92 & 10.34 & 20.34 \\
\hline $\mathrm{T}_{21}$ & $\mathrm{Ca}_{3} \mathrm{~B}_{1} \mathrm{Zn}_{3}$ & 1.92 & 10.11 & 20.67 \\
\hline $\mathrm{T}_{22}$ & $\mathrm{Ca}_{3} \mathrm{~B}_{2} \mathrm{Zn}_{1}$ & 2.23 & 9.45 & 18.44 \\
\hline $\mathrm{T}_{23}$ & $\mathrm{Ca}_{3} \mathrm{~B}_{2} \mathrm{Zn}_{2}$ & 0.00 & 8.72 & 17.11 \\
\hline $\mathrm{T}_{24}$ & $\mathrm{Ca}_{3} \mathrm{~B}_{2} \mathrm{Zn}_{3}$ & 0.00 & 8.45 & 15.78 \\
\hline $\mathrm{T}_{25}$ & $\mathrm{Ca}_{3} \mathrm{~B}_{3} \mathrm{Zn}_{1}$ & 1.67 & 9.11 & 17.34 \\
\hline $\mathrm{T}_{26}$ & $\mathrm{Ca}_{3} \mathrm{~B}_{3} \mathrm{Zn}_{2}$ & 0.00 & 8.45 & 15.56 \\
\hline $\mathrm{T}_{27}$ & $\mathrm{Ca}_{3} \mathrm{~B}_{3} \mathrm{Zn}_{3}$ & 0.00 & 8.22 & 15.23 \\
\hline SEn & & 0.17 & 0.24 & 0.45 \\
\hline C.D & & 0.55 & 0.62 & 1.26 \\
\hline
\end{tabular}

Here- $\mathrm{Ca}_{1-}$ Calciun nitrate $1 \%, \mathrm{~B}_{1-}$ Boric acid $0.2 \%, \mathrm{Zn}_{1-}$. Zinc sulphate $0.2 \% ; \mathrm{Ca}_{2-}$ Calciun nitrate $2 \%, \mathrm{~B}_{2-}$ Boric acid 0.4 $\%, \mathrm{Zn}_{2-}$ Zinc sulphate $0.4 \% ; \mathrm{Ca}_{3-}$ Calciun nitrate $3 \%, \mathrm{~B}_{3-}$ Boric acid $0.6 \%, \mathrm{Zn}_{3-}$ Zinc sulphate $0.6 \%$

(calcium nitrate@3.0\%+boric acid@0.6\%+Zinc sulphate@ $0.6 \%$ ) at $15^{\text {th }}$ day of storage at ambient temperature respectively, which was closely followed by $\mathrm{T}_{26}, \mathrm{~T}_{24}$ and $\mathrm{T}_{23}$ treatments. However, the maximum decay per cent $(28.44 \%)$ was recorded under control at $15^{\text {th }}$ day of storage. The decay loss of fruit increased with the advancement of storage period and calcium, zinc and boron treated fruits show the minimum decay loss (Dawood et al. (2002). Spoilage due to disease incidence was higher at ambient temperature. Similar results have also been reported by Amir et al., (2003), Yang and Lee (2003) and Chaturvedi et al., (2007) whose reported the decay loss of fruit increased with the advancement of storage period in Kinnow, Satsuma mandarin and Guava, irrespectively.

The data in Table 3 reveal that the overall sensory score based on colour, aroma and test of mandarin fruit decreased with the advancing period of storage at room temperature. The highest score $(9.15 / 10),(9.05 / 10)$, $(8.81 / 10)$ and $(8.41 / 10)$ were recorded with treatments T27 (calcium nitrate@3.0\%+boric acid@0.6 $\%+$ Zinc sulphate @ $0.6 \%$ ) at $0^{\text {th }}, 5^{\text {th }}, 10^{\text {th }}$ and $15^{\text {th }}$ day of storage, respectively which was closely followed by $\mathrm{T}_{24}$ and $\mathrm{T}_{26}$ treatments. However, minimum sensory score $(7.58 / 10),(7.23 / 10)(6.76 / 10)$ and $(6.39 / 10)$ were recorded under control at $0^{\text {th }}, 5^{\text {th }}, 10^{\text {th }}$ and $15^{\text {th }}$ day of storage at ambient temperature, respectively. It was probably due to delayed ripening in fruits, retardation of moisture loss, rotting and shrinkage. It may be assumed that higher rate of losses in weight during storage might have been due to raised energy requirement during storage. The similar results have also been reported by Robson et al. (1999) and Patel and Tiwari (2014) who reported overall sensory score based on colour, aroma and test decreased with the advancing period of storage at room temperature in Peach and guava, irrespectively.

The juice percent of Nagpur mandarin during storage reduced with the advancement of storage periods at room temperature (Table-4).The Fruit treated with (calcium nitrate@3.0\%+boric acid@0.6\%+Zinc sulphate@0.6\%) retained maximum juice per cent at the end of storage period. Higher retention of juice per cent of mandarin fruits $(46.31 \%),(44.52 \%),(41.77 \%)$ 
Table 3. Interaction effect of pre-harvest spray of calcium nitrate, boric acid and zinc sulphate on sensory score at $0^{\text {th }}, 5^{\text {th }}, 10^{\text {th }}$ and $15^{\text {th }}$ day of storage of Nagpur mandarin.

\begin{tabular}{|c|c|c|c|c|c|}
\hline & \multirow[t]{2}{*}{ Treatments } & \multicolumn{4}{|c|}{ Sensory score } \\
\hline & & On the day of storage & 5-days & 10-days & 15-days \\
\hline $\mathrm{T}_{0}$ & $\mathrm{Ca}_{0} \mathrm{~B}_{0} \mathrm{Zn}_{0}$ & 7.58 & 7.23 & 6.76 & 6.39 \\
\hline $\mathrm{T}_{1}$ & $\mathrm{Ca}_{1} \mathrm{~B}_{1} \mathrm{Zn}_{1}$ & 7.64 & 7.34 & 6.96 & 6.46 \\
\hline $\mathrm{T}_{2}$ & $\mathrm{Ca}_{1} \mathrm{~B}_{1} \mathrm{Zn}_{2}$ & 7.67 & 7.47 & 7.05 & 6.55 \\
\hline $\mathrm{T}_{3}$ & $\mathrm{Ca}_{1} \mathrm{~B}_{1} \mathrm{Zn}_{3}$ & 7.70 & 7.52 & 7.08 & 6.58 \\
\hline $\mathrm{T}_{4}$ & $\mathrm{Ca}_{1} \mathrm{~B}_{2} \mathrm{Zn}_{1}$ & 7.80 & 7.61 & 7.18 & 6.68 \\
\hline $\mathrm{T}_{5}$ & $\mathrm{Ca}_{1} \mathrm{~B}_{2} \mathrm{Zn}_{2}$ & 7.82 & 7.62 & 7.22 & 6.72 \\
\hline $\mathrm{T}_{6}$ & $\mathrm{Ca}_{1} \mathrm{~B}_{2} \mathrm{Zn}_{3}$ & 7.98 & 7.79 & 7.39 & 6.89 \\
\hline $\mathrm{T}_{7}$ & $\mathrm{Ca}_{1} \mathrm{~B}_{3} \mathrm{Zn}_{1}$ & 7.50 & 7.31 & 6.91 & 6.42 \\
\hline $\mathrm{T}_{8}$ & $\mathrm{Ca}_{1} \mathrm{~B}_{3} \mathrm{Zn}_{2}$ & 7.98 & 7.79 & 7.36 & 6.86 \\
\hline $\mathrm{T}_{9}$ & $\mathrm{Ca}_{1} \mathrm{~B}_{3} \mathrm{Zn}_{3}$ & 8.07 & 7.88 & 7.50 & 7.00 \\
\hline $\mathrm{T}_{10}$ & $\mathrm{Ca}_{2} \mathrm{~B}_{1} \mathrm{Zn}_{1}$ & 8.02 & 7.84 & 7.46 & 6.96 \\
\hline $\mathrm{T}_{11}$ & $\mathrm{Ca}_{2} \mathrm{~B}_{1} \mathrm{Zn}_{2}$ & 7.88 & 7.72 & 7.32 & 6.84 \\
\hline $\mathrm{T}_{12}$ & $\mathrm{Ca}_{2} \mathrm{~B}_{1} \mathrm{Zn}_{3}$ & 8.08 & 7.90 & 7.56 & 7.08 \\
\hline $\mathrm{T}_{13}$ & $\mathrm{Ca}_{2} \mathrm{~B}_{2} \mathrm{Zn}_{1}$ & 7.58 & 7.43 & 7.10 & 6.62 \\
\hline $\mathrm{T}_{14}$ & $\mathrm{Ca}_{2} \mathrm{~B}_{2} \mathrm{Zn}_{2}$ & 8.13 & 7.97 & 7.67 & 7.23 \\
\hline $\mathrm{T}_{15}$ & $\mathrm{Ca}_{2} \mathrm{~B}_{2} \mathrm{Zn}_{3}$ & 8.17 & 8.01 & 7.71 & 7.27 \\
\hline $\mathrm{T}_{16}$ & $\mathrm{Ca}_{2} \mathrm{~B}_{3} \mathrm{Zn}_{1}$ & 8.49 & 8.33 & 8.03 & 7.59 \\
\hline $\mathrm{T}_{17}$ & $\mathrm{Ca}_{2} \mathrm{~B}_{3} \mathrm{Zn}_{2}$ & 8.26 & 8.10 & 7.82 & 7.38 \\
\hline $\mathrm{T}_{18}$ & $\mathrm{Ca}_{2} \mathrm{~B}_{3} \mathrm{Zn}_{3}$ & 8.75 & 8.59 & 8.31 & 7.89 \\
\hline $\mathrm{T}_{19}$ & $\mathrm{Ca}_{3} \mathrm{~B}_{1} \mathrm{Zn}_{1}$ & 8.63 & 8.47 & 8.19 & 7.77 \\
\hline $\mathrm{T}_{20}$ & $\mathrm{Ca}_{3} \mathrm{~B}_{1} \mathrm{Zn}_{2}$ & 8.25 & 8.11 & 7.85 & 7.43 \\
\hline $\mathrm{T}_{21}$ & $\mathrm{Ca}_{3} \mathrm{~B}_{1} \mathrm{Zn}_{3}$ & 8.76 & 8.62 & 8.36 & 7.94 \\
\hline $\mathrm{T}_{22}$ & $\mathrm{Ca}_{3} \mathrm{~B}_{2} \mathrm{Zn}_{1}$ & 8.45 & 8.32 & 8.06 & 7.64 \\
\hline $\mathrm{T}_{23}$ & $\mathrm{Ca}_{3} \mathrm{~B}_{2} \mathrm{Zn}_{2}$ & 8.80 & 8.67 & 8.42 & 8.00 \\
\hline $\mathrm{T}_{24}$ & $\mathrm{Ca}_{3} \mathrm{~B}_{2} \mathrm{Zn}_{3}$ & 9.10 & 8.98 & 8.73 & 8.33 \\
\hline $\mathrm{T}_{25}$ & $\mathrm{Ca}_{3} \mathrm{~B}_{3} \mathrm{Zn}_{1}$ & 8.84 & 8.72 & 8.46 & 8.04 \\
\hline $\mathrm{T}_{26}$ & $\mathrm{Ca}_{3} \mathrm{~B}_{3} \mathrm{Zn}_{2}$ & 9.04 & 8.94 & 8.69 & 8.29 \\
\hline $\mathrm{T}_{27}$ & $\mathrm{Ca}_{3} \mathrm{~B}_{3} \mathrm{Zn}_{3}$ & 9.15 & 9.05 & 8.81 & 8.41 \\
\hline SEn & & 0.18 & 0.11 & 0.08 & 0.07 \\
\hline C.D & & 0.52 & 0.34 & 0.23 & 0.22 \\
\hline
\end{tabular}

Here- $\mathrm{Ca}_{1}$ - Calciun nitrate $1 \%, \mathrm{~B}_{1-}$ Boric acid $0.2 \%, \mathrm{Zn}_{1}$ - Zinc sulphate $0.2 \% ; \mathrm{Ca}_{2-}$ Calciun nitrate $2 \%, \mathrm{~B}_{2-}$ Boric acid 0.4 $\%, \mathrm{Zn}_{2}$. Zinc sulphate $0.4 \% ; \mathrm{Ca}_{3-}$ Calciun nitrate $3 \%, \mathrm{~B}_{3-}$ Boric acid $0.6 \%, \mathrm{Zn}_{3}$ - Zinc sulphate $0.6 \%$

and $(39.12 \%)$ were recorded maximum with treatment $\mathrm{T}_{27}$ (calcium nitrate@3 per cent + boric acid@0.6 per cent + Zinc sulphate @ 0.6 per cent) at $0^{\text {th }}$, $5^{\text {th }}, 10^{\text {th }}$ and $15^{\text {th }}$ day of storage at ambient temperature, respectively. while, minimum juice per cent $(35.20 \%),(31.83 \%),(27.40 \%)$ and $(25.90 \%)$ was recorded under control at $0^{\text {th }}, 5^{\text {th }}, 10^{\text {th }}$ and $15^{\text {th }}$ day of storage, respectively. It was probably due to moisture loss from the rind of epidermal cells during storage and also drying of juice vesicles indicating that the fruit juice contents decreased with increasing storage durations irrespective of foliar spray. The increase in fruit juice contents of plant sprayed with micronutrients might be due to active absorption of micronutrients mobilizing them to the active sites of fruit development. The present results of retained maximum juice per cent was observed by Amir et al. (2003) in Kinnow, Yang and Lee (2003) in Satsuma mandarin and Sajidet al. (2012) in sweet Orange.

\section{Conclusion}

The study concluded that mandarin (C. reticulata) should be stored at ambient temperature $\left(25 \pm 2{ }^{\circ} \mathrm{C}\right)$ to retain better shelf life for longer period. Among different pre-harvest treatments, $\mathrm{T}_{27}$ treatment $(\mathrm{Ca} 3.0 \%+\mathrm{B}$ $0.6 \%+\mathrm{Zn} 0.6 \%$ ) treated fruits had the longest shelflife of 15 days with lowest PLW (9.27\%), decay per cent $(15.23 \%)$ and better organoleptic ratting $(8.41 / 10)$ and higher retention of juice per cent $(39.12$ $\%$ till end of storage period. Thus, minimizing postharvest losses and increasing consumer's acceptability by maintaining the different quality parameters for long time during storage provided the great market potential for the "Nagpur mandarin" fruits.

\section{REFERENCES}

Amir, M., Chaturvedi, O.P. and Tripathi, V.K. (2003). Effect of pre-harvest application of gibberellic acid and calcium nitrate on the fruit maturity and storage quality of Kinnow Mandarin. Farm Science Journal, 12 (2): 148149.

Anonymous (2015). Assistant Director Horticulture, Department of Horticulture Jhalawar. Pp 2.

Anonymous (2015) Indian Horticulture Database, (2014). Published from Nationaln Horticulture Board, Gurga- 
Table 4. Interaction effect of pre-harvest spray of calcium nitrate, boric acid and zinc sulphate on juice per cent at $0^{\text {th }}, 5^{\text {th }}, 10^{\text {th }}$ and $15^{\text {th }}$ day of storage of Nagpur mandarin.

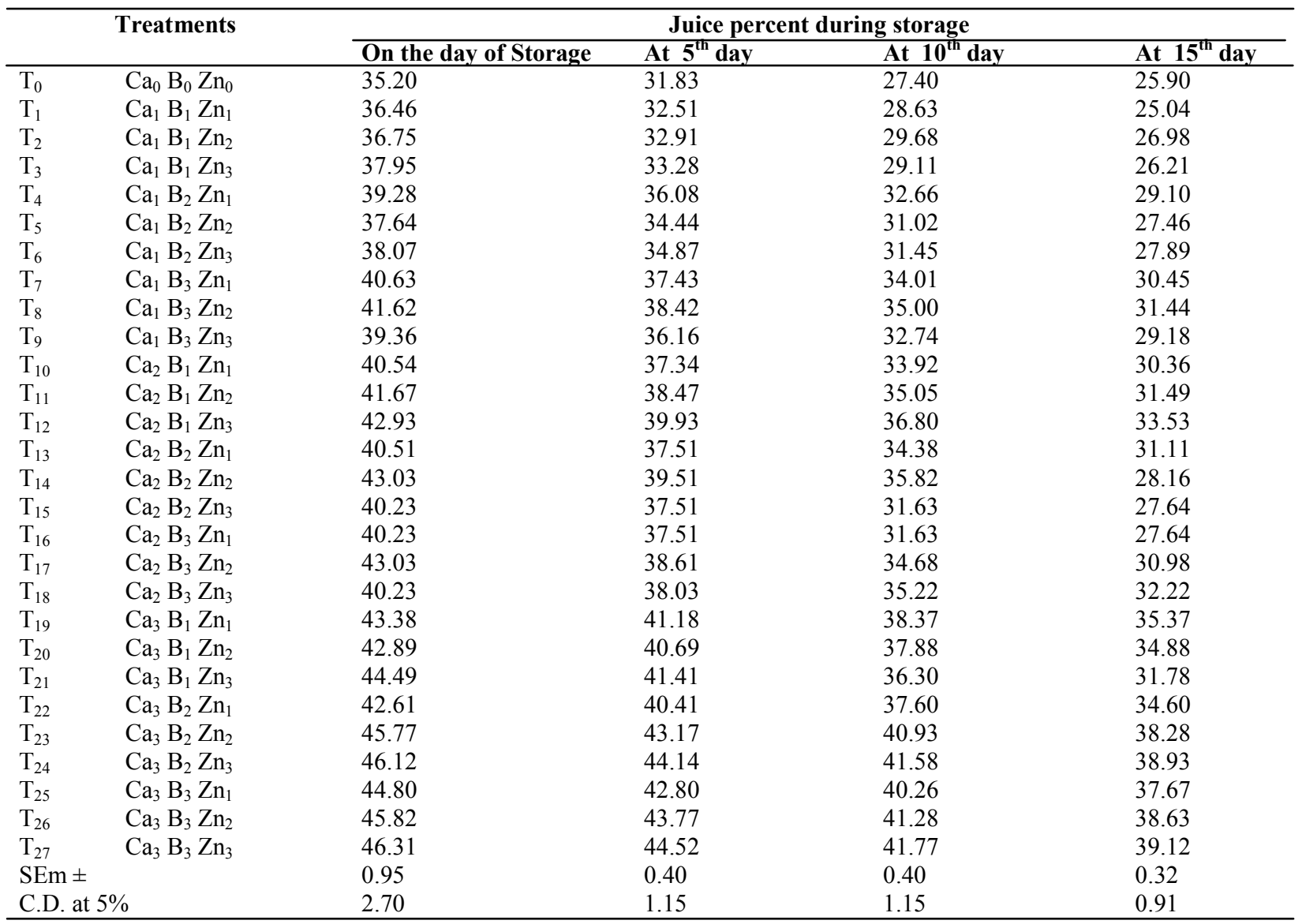

Here- $\mathrm{Ca}_{1-}$ Calciun nitrate $1 \%, \mathrm{~B}_{1-}$ Boric acid $0.2 \%, \mathrm{Zn}_{1-}$. Zinc sulphate $0.2 \% ; \mathrm{Ca}_{2-}$ Calciun nitrate $2 \%, \mathrm{~B}_{2-}$ Boric acid 0.4 $\%, \mathrm{Zn}_{2-}$ Zinc sulphate $0.4 \% ; \mathrm{Ca}_{3-}$ Calciun nitrate $3 \%, \mathrm{~B}_{3-}$. Boric acid $0.6 \%, \mathrm{Zn}_{3}$ - Zinc sulphate $0.6 \%$

on,Pp.118-121.

Chaturvedi, R.S., Gaur, O. P. and Singh, G. (2007). Effect of pre-harvest spray of zinc, calcium and boron on the storage behaviour of guava (Psidiumguajava L.) fruits cv. Allahabad Safeda. Acta Horticulturae, 7 (35): 633638.

Dawood, S. A., Meligy, M. S. and El-Hamady, M. M. (2002) Influence of pre harvest spray of calcium nitrate, zinc sulphate and boric acid on quality and shelf life of Balady mandarin. Annals of Agricultural Science, 39(1): 433-447.

Fisher, R.A., (1950) Statistical methods for research workers. Oliver and Boyd, Edinburgh.

Patel, V. and Tiwari, R. (2014) Effect of pre-harvest spray of nutrients on delayed ripening and prolonged storability of guava fruits. Annals of Plant and Soil Research, 16 (4): 327-329.

Robson, M.G., Hopfinger, J. and. Eck, P. (1999) Postharvest sensory evaluation of calcium and zinc treated peach fruit. Acta Hort., 25 (4):173-177.

Sajid, M., Rab, A., Tanveer, S., Iqbal, A., Zamin, M. and Shakur, M. (2012) Pre-harvest treatment of $\mathrm{Zn} \mathrm{\&} \mathrm{B}$ affects the fruit quality and storability of sweet orange. J. Agric. Sci. and Technol., 2(2):1224-1233.

Yang, Y. J. and Lee, K. A. (2003) Postharvest quality of Satsuma mandarin fruit affected by pre harvest spray of micronutrients. Acta Horticulturae, 41(600): 775-779. 